\title{
Comparative performance of Giriraja chicken reared on different feeding regimes for economic production in Nepal
}

\author{
Neupane $D^{1 *}$, BB Bhandari, S Poudel, S Shrestha and S Sapkota ${ }^{2}$
}

${ }^{1}$ Swine and Avian Research Program, Khumaltar, Nepal Agricultural Research Council (NARC), ${ }^{2}$ Animal Breeding Division, NARC, Khumaltar, Kathmundu, Nepal

\begin{abstract}
The experiment was conducted to study the comparative performance of Gririaja birds reared on different feeding regime in Nepal. A total of 384 Giriraja birds of aged 40 weeks were assigned to four treatment groups in four replications with 24 birds (20 female and 4 male) per replication over a period of 180 days. The birds of control group were provided with $130 \mathrm{~g}$ of feed in confinement. In group 1 , $10 \%$ feed was replaced by green seasonal forage mainly oat and birds were kept on scavenging, while in group 2, $10 \%$ feed was replaced by similar forage but the birds were in confinement. However, in group 3, birds were provided $10 \%$ less feed on scavenging without forage supplementation. The result showed that the feed consumption required for dozen of egg production was lower $(P<0.01)$ at 2610 $\mathrm{g} / \mathrm{bird}$ in group 1 and higher ( $3114 \mathrm{~g} / \mathrm{bird}$ ) in control group. The birds kept in control and in group 1 was found significantly $(P<0.05)$ superior in egg production as compared with the second and third treatment groups (15.05 and 16.15 vs. 15.55 and 14.31 in number, respectively). There was no significant difference on egg weight between the groups. Feed cost for dozen of egg production was recorded $\$ 1.17$ and more gross returns from sale of eggs $(\$ 0.27)$ was observed in treatment group 1 but less return ( $\$ 0.04$ ) was obtained from control group. The result showed that rearing of Gririaja birds with forage supplementation having the facilities of outdoor range is a good profitable venture, considering the minimum feed consumption and feed cost with maximum egg production.
\end{abstract}

Key words: Giriraja chicken, forage supplementation, outdoor range, feeding cost, egg production

Bangladesh Animal Husbandry Association. All rights reserved. $\quad$ Bang. J. Anim. Sci. 2017. 46 (2): 134-139

\section{Introduction}

Poultry sector is an emerging industry in Nepal with distinct patterns of poultry production - free range scavenging system to intensive system. The scavenging poultry is widely prevalent in the rural areas where $45 \%$ of total poultry population comprises of native flock, which could create agro-entrepreneurship leading to sustainable livelihood security. Though the eggs and meats of indigenous breed fetched high price in the market, the low productivity of the breed could not meet the consumers demand (Bhurtel and Sah et al., 2000). Therefore, for upgrading indigenous breeds in rural areas, "Giriraja" a synthetic colored dual-purpose strain resemble local fowl introduced in 1970's in the country. Study and resistant, it can easily acclimatize itself to any region and weather and perform better even in scavenging management (Aryal and Neupane, 1997; Shrestha, 2000). Its faster growth habit and higher egg laying capacity than indigenous birds have made marked improvement in livelihood of the farming community.
Giriraja has been already proven as breed suitable for free- range and semi-intensive system. Though the breed is low producer than exotic breeds, they can fetch higher market price due to their meat quality as closely resembles to native chicken. Looking at their potentialities, the small-scale broiler producer and medium farmers have shown their keen interest in rearing such breed with intensive system of management. However, cost of production of per kg of poultry meat has been increased day by day due to uncontrolled rise of price of feed ingredients. High cost of feed and treatment is contributing more than $75 \%$ of total cost of production. Any effort to improve feed efficiency through knowledge of poultry nutrition and feeding will go a long way to improve the profit margin of poultry farmers (Singh, 1997). Therefore, the present study was carried out to assess the comparative performance of Giriraja birds reared on different feeding regimes for economic production.

*Corresponding author: damodarneupane@ymail.com 


\section{Materials and Methods}

\section{Bird selection}

Present study was carried out at farm of Swine and Avian Research Program, Nepal Agricultural Research Council (NARC), Khumaltar, Nepal during January 2016 to June, 2016 for 180 days. Total, 384 Giriraja birds of aged 40 weeks were randomly divided into four treatment groups with four replication having 24 birds (20 female and 4 male) in each replication following completely randomized design.

\section{Shed management and feeding regime}

The birds were kept in deep litter system and fed recommended quantity of commercial mesh feed (having nutrient content as in table 1) two times in a day, with fresh and clean drinking water adlibitum. The birds in control group was provided with $130 \mathrm{gm}$ of feed and kept in confinement while in group 1 and groups 2, 10\% feed was replaced on DM basis with green seasonal forage mainly oat having nutrient content as in table 1 . However, the birds in group1 had facilities of outdoor range for scavenging while in group 2 birds were kept in confinement. Similarly, $10 \%$ less feed was given for 3rd group without forage supplementation but have access of outdoor range for scavenging (grazed outside for a period of 4 to 6 hrs a day). Details are following:

\begin{tabular}{|c|c|}
\hline Groups & Feeding regime \\
\hline Control & $130 \mathrm{~g}$ of feed/bird in confinement \\
\hline Group 1 & $\begin{array}{l}117 \mathrm{~g} \text { of feed/bird }+42 \mathrm{~g} \text { of } \\
\text { forage/bird }+ \text { Scavenging }\end{array}$ \\
\hline Group 2 & $\begin{array}{l}117 \mathrm{~g} \text { of feed/bird }+42 \mathrm{~g} \text { of } \\
\text { forage/bird }+ \text { No Scavenging }\end{array}$ \\
\hline Group 3 & $\begin{array}{l}117 \mathrm{~g} \text { of feed/bird }+ \text { No forage } \\
\text { supplement }+ \text { Scavenging }\end{array}$ \\
\hline
\end{tabular}

The forage was cut in the morning, sun dried and chopped in small pieces and given with concentrate feed to the chicken. Medication and vaccinations were done as and when needed. Proper sanitation programme was applied during the experiment period.

\section{Chemical analysis}

The sample of concentrate feed and forage supplied during the experimental period were analysed for Proxmate analysis (AOAC, 1984) in Animal Nutrition Lab, Khumaltar.
Table 1. Chemical composition of experimental feed and forage

\begin{tabular}{lll}
\hline Parameter & $\begin{array}{l}\text { Commercial } \\
\text { concentrate } \\
\text { feed }\end{array}$ & $\begin{array}{l}\text { Green } \\
\text { forage }\end{array}$ \\
\hline Dry Matter & 87.24 & 30 \\
Crude protein & 18.25 & 5.55 \\
Energy( Kcal/kg) & 2590 & 9.65 \\
Total Ash & 7.90 & 9.95 \\
Organic matter & 92.10 & 90.1 \\
\hline
\end{tabular}

\section{Data Recording}

The data on body weight of male was recorded at monthly interval and body weight gain was calculated. Daily egg production was record and monthly egg production was calculated. All the eggs produced on two weeks interval were collected separately for different treatment groups and weighed individually with an electronic scale. The amount of feed quantity offered was also recorded daily and feed required for dozen of egg production was calculated. The economics of egg production based on feed consumption was calculated. The cost of feed was worked out considering the prevalent cost of feeds.

\section{Data analysis}

The experimental data were analyzed by SPSS 16, computer software and means were compared by DMRT.

\section{Results and Discussion}

\section{Male body weight gain}

The average body weight gain of male Giriraja birds has been presented in the table 2 . Analysis of data on mean male body weight and body weight gain revealed no significant difference between the treatment groups, which might be due to additional nutrient intake from forage and from outdoor range for some replacement of concentrate. However monthly body weight gain and total body weight gain of Male Giriraja found numerically higher in group 1 and lower in control group. It was reported that inclusion of moderate level insoluble fibres with some reduced nutrient concentration in diets do not have a negative effect on production performance of broilers or layers (Hetland and Sivhus, 2001 and Hetland et al., 2002). In this study, mean live body weight of male Giriraja at the end of experiment (at 65 wks of age) was $3.65 \mathrm{~kg}$ which is near to the finding of Shrestha et al. (2010), who reported that the average 70 weeks of male Griraja chicken was $4.0 \pm 1.9 \mathrm{~kg}$. 
Neupane et al. (2017) Bang. J. Anim. Sci. 46 (2):134-139

Table 2. Average body weight gain of male Giriraja birds during the experimental period

\begin{tabular}{|c|c|c|c|c|c|c|}
\hline \multirow[t]{2}{*}{ Parameters } & \multicolumn{4}{|c|}{ Groups } & \multirow[t]{2}{*}{ Mean \pm SE } & \multirow{2}{*}{$\begin{array}{l}P \\
\text { value }\end{array}$} \\
\hline & Control & 1 & 2 & 3 & & \\
\hline Live weight (kg) & 3.69 & 3.46 & 3.65 & 3.35 & $3.55 \pm 0.20$ & NS \\
\hline Monthly weight gain (g) & 89.36 & 102.04 & 92.48 & 95.24 & $94.78 \pm 0.51$ & NS \\
\hline $\begin{array}{l}\text { Total body weight gain } \\
(\mathrm{gm})\end{array}$ & 446.80 & 510.20 & 462.40 & 476.20 & $473.9 \pm 26$ & NS \\
\hline
\end{tabular}

NS: Means values alongs rows are non-significantly different $(P<0.05)$

\section{Monthly egg production and Feed Consumption}

Data concerning average monthly egg production of different groups of Giririaja are presented in Table 3 and in Fig 1. Average monthly egg production of bird differed significantly $(P<0.05)$ among the treatment group. The bird kept in confinement as in control group and birds in group 1 ; both the groups were found superior in egg production as compared with other treatment groups. Similarly, feed consumption per dozen of egg production of the different treatment group are represented in Table 3. The feed consumption calculated based on of dozen of egg produced was significantly $(P<0.01)$ lower at $2610 \mathrm{~g} /$ bird in group 1 and higher ( $3114 \mathrm{~g} / \mathrm{bird})$ in control group than other treatment groups. Recent research demonstrated that the intake of forage materials decreased layer diet intake without altering egg production which suggests that forage materials can supply nutrients to the hens (Hammershoj et al., 2010; Steenfeldt et al., 2007; Horsted, 2006). Bassler et al. (1997) found that a $15 \%$ reduction in the concentrate fed to layers had no detrimental effect on egg production, whereas individual herbage consumption was as high as $30 \mathrm{~g}$ DM per day. The intake of forage materials may in general reduce the feed consumption by up to $20 \%$ (Blair, 2008). Similarly, Steenfeldt et al. (2007) reported that a $12 \%$ reduction in layer diet intake was possible without altering egg production when birds were fed $108 \mathrm{~g} / \mathrm{hen} / \mathrm{d}$ carrot as forage.

Table 3. Average monthly egg production, egg weight and feed consumption per dozen of egg production of different groups of Giriraja birds during the experimental period

\begin{tabular}{|c|c|c|c|c|c|c|c|}
\hline \multirow{2}{*}{\multicolumn{2}{|c|}{ Parameters }} & \multicolumn{4}{|c|}{ Treatments } & \multirow[t]{2}{*}{ Mean \pm SE } & \multirow{2}{*}{$\begin{array}{l}\mathbf{P} \\
\text { value }\end{array}$} \\
\hline & & Control & 1 & 2 & 3 & & \\
\hline $\begin{array}{l}\text { Monthly egg } \\
\text { (no.) }\end{array}$ & Production & $15.05^{\mathrm{a}}$ & $16.15^{a}$ & $14.55^{\mathrm{b}}$ & $14.31^{\mathrm{b}}$ & $15.01 \pm 0.10$ & $*$ \\
\hline \multicolumn{2}{|c|}{$\begin{array}{l}\text { Feed consumption per dozen } \\
\text { of egg ( } \mathrm{gm})\end{array}$} & $3114^{b}$ & $2610^{a}$ & $2906^{b}$ & $2976^{b}$ & $2902 \pm 5.57$ & $* *$ \\
\hline \multicolumn{2}{|l|}{ Egg weight (gm) } & 56.10 & 57.35 & 56.5 & 56.80 & $56.69 \pm 0.17$ & NS \\
\hline
\end{tabular}

${ }^{a-b}$ values with different superscripts in the same row differ significantly. $*$ Significant at $5 \%$ level, ** Significant at $1 \%$ level, NS: non-significant 


\section{Fig.1. Monthly egg production of differnt group of Giriraja birds}

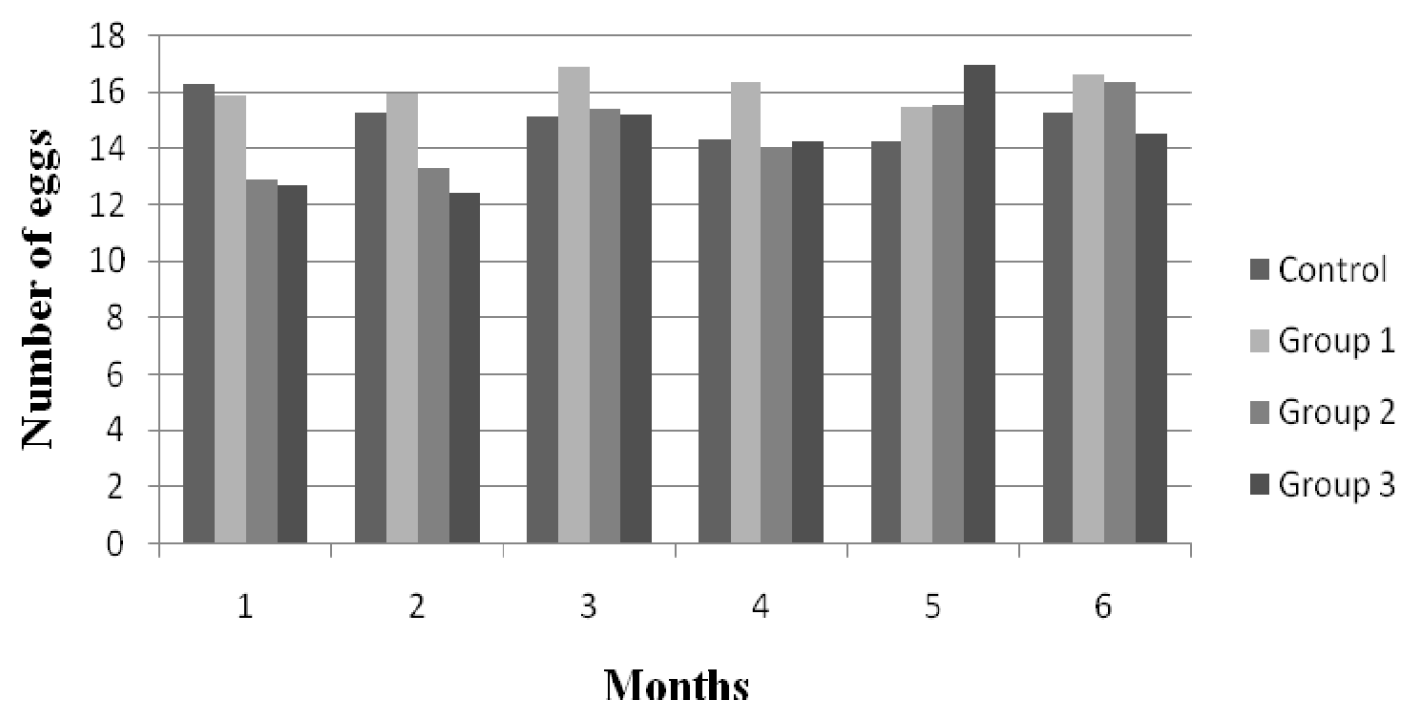

\section{Egg weight}

Egg weight results of different group of Giriraja among the different treatments are shown in Table 3. Presented result indicated that there was no significant difference among the treatments in egg weight though the highest egg weight i.e $57.35 \mathrm{gm}$ was record in group 1 than other treatment groups. Average egg weight of Giririaja in the present study found $56.69 \mathrm{gm}$ and the result is in close agreement with the findings of Bharambe and Garud (2012). Sah et al. (2007) reported that the average egg weight of Giriiraja was $60 \mathrm{gm}$, which is slightly higher to our result. In the present study, no significant difference observed on egg weight between different dietary treatments and result agreed with the Mugna et al. (2009) who stated that the egg weight was not affected $(P<0.05)$ by the husbandry system or season. Drinceanu et al. (2011) reported that the mean egg weight is not influenced by feed's microelement level and the differences between groups are not statistically grassured. It was also reported that green forage or grass provides additional source of lysine, methionine (Horsted and Hermansen, 2007) and calcium (Horsted, 2006) that all are essential for egg formation.

\section{Economics of egg production}

Relation of feed to egg production and return from the sale of egg are presented in table 4 . Data revealed that average minimum feed consumption with minimum total feed cost ( $\$$ 1.17) for dozen of egg production and more gross returns ( $\$ 0.27$ ) was observed in group 1 . On other hand, the maximum total feed cost ( $\$ 1.40)$ required for dozen of egg production with minimum return from sale of egg $(\$ 0.04)$ was observed in control group or the bird reared in confinement. Meanwhile, feed replaced with forage in confinement as in group 2 or birds on scavenging without forage supplementation as in group 3; both the group found to be profitable in terms of feed consumption and economics of egg production than from the birds grouped in confinement. As in our study, various research shows that rearing the birds with forage or grass supplementation proved to be economical in terms of cost of production. It was found that the average profit of bird was Rs. 159 when it was kept under formulated balance compound feed as its basal diet and profit of Rs 239 per bird can be obtained if $20 \%$ berseem grass is included in its basal diet (Annual report, SARP, 2062/63). 
Neupane et al. (2017) Bang. J. Anim. Sci. 46 (2):134-139

Table 4. Economics' of feed and egg production of different groups of Giriraja birds during the experimental period

\begin{tabular}{|c|c|c|c|c|}
\hline \multirow[t]{2}{*}{ Parameters } & \multicolumn{4}{|c|}{ Groups } \\
\hline & Control & 1 & 2 & 3 \\
\hline $\begin{array}{l}\text { Feed consumption per dozen of egg } \\
\text { production }(\mathrm{gm})\end{array}$ & 3114 & 2610 & 2906 & 2976 \\
\hline Feed cost/kg $(\$)$ & 0.45 & 0.45 & 0.45 & 0.45 \\
\hline $\begin{array}{l}\text { Total cost of feed for dozen of eggs } \\
\text { production ( } \$ \text { ) }\end{array}$ & 1.40 & 1.17 & 1.30 & 1.33 \\
\hline $\begin{array}{l}\text { Income from sale of dozen egg @ } \$ \\
0.12 / \text { egg }\end{array}$ & 1.44 & 1.44 & 1.44 & 1.44 \\
\hline Gross return form dozen eggs $(\$)$ & 0.04 & 0.27 & 0.14 & 0.11 \\
\hline
\end{tabular}

$1 \$=100$ Nepali Rupees

\section{Conclusion}

The study concluded that feed consumption was lower with higher egg production with maximum gross return from the sale of eggs from groups of birds supplied with forage with access of outdoor range than the birds in confinement. Therefore, rearing of Giriraja with forage supplementation having the facilities of outdoor range is a good profitable venture, considering the minimum feed consumption and feed cost with maximum egg production. In addition, it is profitable if Giriraja birds in confinement supplied with forage or having assess of outdoor range than the bird completely kept in confinement with commercial feed as basal diet.

\section{Acknowledgement}

The authors are thankful to the Director of Animal Nutrition Division, Khumaltar, Dr. Megraj Tiwari for providing lab facilities and guidance to carry out the research works. The other necessary supports provided by the staffs of Swine and Avian Research Program Khumaltar, are also duly acknowledged.

\section{References}

Annual report SARP (2062/063). Swine and Avian Rsearch Program, Nepal Agriuclutral Research Council, Khumaltar, Nepal.

AOAC (1984). Official methodsof analysis. $14^{\text {th }}$ Edn. Association of Official Analaytical Chemist, Washington, DC, USA.
Aryal IK and SP Neopane (1997). Performance of Giriraja chicken in the eastern hills of Nepal. PAC technical paper. Pakhribas Agricultural Centre, Dhnakuta. 179:14.

Bassler A, P Ciszuk and K Sjelin (1997). Management of laying hens in mobile houses-a review of experiences. DARCOF Report 2/2000. pp. 45-50.

Bhurtel R and BKP Shaha (2000). Poultry development in Nepal, constraints and potentialities. Research report 45 . Winrock International. Pp. 51

Blair R (2008). Nutrition and Feeding in Organic Poultry. CAB International Publishing, Oxfordshire, UK.

Drinceanu D, JJ Colin, S Eliza, O Lavinia, L Ioan and S Domnica (2011). Effects of Mineral Supplements on Bioproductive Results in Egg-Laying Hens Farmed in Organic Systems. Sci. Papers: Animal Science and Biotechnologies, 1: 44

Hammershoj M, U Kidmose and S Steenfeldt (2010). Deposition of carotenoids in egg yolk by short-term supplements of coloured carrot (Daucus carota)varieties as forage material for egg laying hens. Journal of the Science of Food and Agriculture, 90: 1163-1171.

Hetland $\mathrm{H}$ and B Svihus (2001). Effect of oat hulls on performance, gut capacity and feed passage time in broiler chickens. British Poultry Science, 42: 354-361.

Hetland H, B Svihus and V Olaisen (2002). Effect of feeding whole cereals on 
performance, starch digestibility and duodenal particle size distribution in broiler chickens. British Poultry Science, 43: 416-423.

Horsted K (2006). Increased Foraging in Organic Layers. PhD Thesis. Department of Agroecology, University of Aarhus. Faculty of Agricultural Sciences. http://orgprints. org/10463/1/10463.pdf

Horsted K, J Hermansen and H Ranvig (2007). Crop content in nutrient-restricted versus nonrestrictedorganic laying hens with access to different forage vegetations. British Poultry Science, 48:177-184.

Mugna C, AD Bosco and C Castellini (2009). Effect of rearing system and season onthe performance and egg characteristics of Ancona laying hens. Italian Journal of Animal Science, 8:175-188.

Sah RB, D Pandit and Y Upendra (2007). Effect of Different Level of Effective Microorgaism (EM) on Egg Production of Giriraja Chicken. Proceedings of the 4th
SAS-N Convetion. 4-6 April. Ktm. Nepal., 4: 268-270.

Shrestha, SB, JN Pradhan, RK Karki, TP Paudel and TS Dhaubhadel (2010). Evaluation of production performance of Giriraja chicken in Dolakha. Proceeding of the Ninth National Outreach Workshop (7-8 June 2010), NARC, Kathmandu. 9: 352-357

Singh RA (1997). Poultry Nutrition, Poultry Production, Kalyani Publications, Ludhiana.

Steenfeldt S, JB Kjaer and RM Engberg (2007). Effects of feeding silages or carrots as supplements to laying hens on production performance, nutrient digestibility, gut structure, gut microflora, and feather pecking behaviour. British Poultry Science, 48: 454-468. 